\title{
Analisis Hukum Surat Pelepasan Hak Atas Tanah Adat (Dati) Di Kota Ambon
}

\author{
Desy Kosita Hallauw $^{1 *}$, Jenny Kristiana Matuankotta ${ }^{2}$, Novyta Uktolseja ${ }^{3}$ \\ 1. Program Magister Ilmu Hukum Fakultas Hukum Universitas Pattimura, Ambon, Indonesia \\ ${ }^{2,3}$ Fakultas Hukum Universitas Pattimura, Ambon, Indonesia \\ *E-mail: desyhallauw@gmail.com
}

\begin{abstract}
Relinquishment of land rights is the relinquishment of legal relations between the holders of land rights and the land under their control by providing compensation on the basis of deliberation. Letter of Waiver of rights is evidence that is made with the aim of releasing land rights. A letter of release of customary land rights (dati) is applied in the same way as the release of land rights in general, as enforced in accordance with Government Regulation No. 24 of 1997 concerning Land Registration. The process of registering customary land rights (dati) is based on the release of customary rights (dati) issued by the customary land owner (dati) as the basis for rights. So based on the release of land rights, it can be registered at the Ambon City Land Office to obtain proof of land ownership or certificates. The letter of release of customary land rights (dati) issued by the customary State Government in Ambon City is binding as long as it is carried out based on applicable customary law and can be proven the basis of ownership rights to customary land (dati) from the customary land owner (dati) that issues the release letter the land rights. However, as long as it cannot be proven valid, the letter of release of land rights does not have binding power, thus the release of the customary land rights (dati) becomes invalid and the certificate can be canceled.
\end{abstract}

Keywords: Waiver of Rights; Customary Land (Dati).

\section{A. PENDAHULUAN}

UUPA sebenarnya secara sadar didesain untuk mengakhiri pluralitas pranata hukum yang mengatur bidang pertanahan dan ingin menciptakan satu tata hukum tanah nasional, dengan menjadikan hukum adat sebagai dasarnya. Perlu dicatat bahwa sekalipun UUPA menggunakan istilah agraria, namun inti pengaturannya lebih berhubungan dengan hukum tanah sebagai bidang hukum utama dari hukum agraria. ${ }^{1}$ Penjelasan Pasal 5 UUPA menyatakan: "Hukum agraria yang berlaku atas bumi, air, dan ruang angkasa ialah hukum adat sepanjang tidak bertentangan dengan kepentingan nasional dan negara, yang berdasarkan atas persatuan bangsa, dengan sosialisme Indonesia serta dengan peraturanperaturan yang tercantum dalam undang-undang ini dan dengan peraturan perundangan

1 Shidarta, (2010), "Peragaan Pola Penalaran Hukum dalam Kajian Putusan Kasus Tanah Adat". Jurnal Yudisial, Vol-III/No-03/Desember/2010, h. 218. 
lainnya, segala sesuatu dengan mengindahkan unsur-unsur yang bersandar pada hukum agama."

Undang-Undang Nomor 5 Tahun 1960 tentang Peraturan Dasar Pokok-pokok Agraria (selanjutnya disebut UUPA) telah memberikan pengakuan terhadap hukum tanah adat dan masyarakat hukum adat. Dengan pengakuan dalam UUPA maka hak-hak adat atas tanah disejajarkan kekuatan mengikatnya dengan hak menurut hukum perdata dan hukum lainnya. ${ }^{2}$

Masyarakat hokum adat yang mendiami seluruh wilayah Indonesia sudah ada sejak jaman nenek moyang sampai saat ini. Masyarakat hokum adat disebut juga masyarakat tradisional diartikan sebagai masyarakat hokum adat yang hidup dengan berbagai perturan kebiasaan yang dipertahankan dalam pergaulan hidup dalam masyarakat adat. ${ }^{3}$

Umumnya tanah-tanah di Daerah Ambon adalah tanah adat yang tunduk kepada dan juga dikuasai oleh hak petuanan (beschikkingsrecht) dari desa atau negeri yang bersangkutan. Tanah-tanah adat ini dapat disebut juga tanah ulayat dan digolongkan kepada tanah Negara yang tidak bebas (niet vriclandsdomein). Dalam perkembangan kemudian sebagian dari tanah petuanan itu lepas dari kekuasaan dan pengaturan langsung dari hak petuanan oleh negeri-negeri yang bersangkutan, karena pada tanah-tanah tersebut telah muncul hak-hak yang bersifat perorangan atau hak-hak lainnya yang lebih kuat dari hak petuanan itu. Penguasaan atas tanah-tanah adat itu oleh hak petuanan bukanlah sekedar untuk dikuasai saja, tetapi juga supaya pemanfaatannya berjalan dengan tertib. $^{4}$

Berbagai bentuk hubungan hukum atas tanah yang berupa hak-hak penguasaan atas tanah memberi wewenang bagi pemegang haknya untuk berbuat sesuatu atas tanah yang dihaki, namun demikian tidak dibenarkan untuk berbuat sewenang-wenang terhadap tanahnya karena disamping kewenangan yang dimilikinya pemegang hak juga mempunyai kewajiban-kewajiban tertentu dan harus memperhatikan larangan-larangan yang berlaku baginya. ${ }^{5}$

Bagi para pihak yang ingin memperoleh tanah, dapat dilakukan melalui berbagai cara antara lain dengan permohonan hak, pembebasan/ pelepasan hak dan pencabutan hak kemudian diikuti dengan permohonan hak baru. Pemindahan hak/ peralihan hak adalah suatu perbuatan hukum yang bertujuan memindahkan hak atas benda bergerak maupun benda tidak bergerak. Perbuatan hukum pemindahan benda tidak bergerak yang berkaitan dengan tanah meliputi jual-beli, hibah, tukar menukar, pemisahan dan pembagian harta bersama serta pemasukan dalam perusahaan atau inbreng. ${ }^{6}$

Disediakan berbagai cara untuk memperoleh tanah yang diperlukan, yang ketentuan-ketentuannya disusun dalam suatu sistem, dimana status tanah yang tersedia ada 2 (dua) macam yaitu Tanah Negara dan Tanah Hak. Tanah negara adalah tanah yang langsung dikuasai negara. Langsung dikuasai artinya tidak ada pihak lain di atas tanah itu, tanah itu disebut juga tanah negara bebas. ${ }^{7}$

2 Suseno, Franz Magnis. (2001). Etika Politik dan Prinsip-prinsip Moral Dasar Negara Modern, Jakarta: Gramedia, h. 53.

3 Uktolseja, Novyta, (2015). Perkembangan Sistim Pewarisan Tanah Dati di Kota Ambon. Disertasi, Universitas Airlangga, h. 1.

${ }^{4}$ Effendi, Ziwar. (1987). Hukum Adat Ambon-Lease. Jakarta: Pradnya Paramita, h. 91.

5 Hutagalung, Arie S. (2005). Tebaran Pemikiran Seputar Masalah Hukum Tanah, Jakarta: Lembaga Pemberdayaan Hukum Indonesia, h.19.

6 Salindeho, John. (1987). Masalah Tanah Dalam Pembangunan, Jakarta: Sinar Grafika, h. 37.

$7 \mathrm{zd}$ 
Hak atas tanah adalah seseorang yang mempunyai hak atas tanah berwenang untuk mempergunakan atau mengambil manfaat atas tanah yang menjadi haknya. Hak-hak atas tanah yang dimaksud ditentukan dalam pasal 16 jo pasal 53 UUPA. Sehingga bila yang tersedia Tanah Hak, maka apakah pemegang haknya bersedia atau tidak untuk menyerahkan atau memindahkan hak atas tanahnya baik dengan cara jual-beli atau pelepasan hak. Sehubungan dengan adanya kesepakatan antara pemegang hak atas tanah dengan pihak lain yang memerlukan tanah dalam penguasaan pemegang hak tersebut, maka cara yang dapat ditempuh adalah dengan pelepasan hak yang kemudian diikuti dengan permohonan hak baru. ${ }^{8}$

Tanah adat di Ambon sebagai pemegang dan pelaksana hak petuanan ini adalah Raja dan Badan Saniri Negeri. ${ }^{9}$ Namun yang menjadi persoalan hukum dikemudian hari adalah ketika tanah dati yang telah dikuasai oleh negeri, kemudian negeri memberikan pelepasan hak kepada orang lain akan tetapi dasar dari pelepasan hak atas tanah dati tersebut dapat dipersoalkan oleh pihak lain sehingga dapat mengakibatkan pembatalan hak. Apakah hal ini berarti pemerintah negeri tidak memiliki legalitas dalam mengeluarkan surat pelepasan hak.

Berdasarkan uraian di atas penulis tertarik untuk melakukan penelitian dan kajian dengan permasalahannya yaitu "Bagaimana Pelaksanaan Pendaftaran Tanah Untuk Memperoleh Hak Baru Berdasarkan Surat Pelepasan Hak Atas Tanah Adat (Dati) di Kota Ambon?, dan Bagaimanakah Kekuatan Mengikat Surat Pelepasan Hak Atas Tanah Adat (Dati) Di Kota Ambon?".

\section{B. METODE PENELITIAN}

Penelitian ini bersifat yuridis normatif oleh karena itu menggunakan data sekunder berupa bahan hukum primer, bahan hukum sekunder dan bahan hukum tersier, dalam melakukan penelitian ini menggunakan pendekatan undang-undang (statute approach) yaitu pendekatan penelitian yang mengutamakan bahan hukum yang berupa peraturan perundang-undangan sebagai bahan acuan dasar. Bahan hukum yang diperoleh selanjutnya dilakukan pembahasan, pemeriksaan dan pengelompokan ke dalam bagianbagian tertentu untuk diolah menjadi data informasi. Hasil analisis bahan hukum kemudian diinterpretasikan. Kegiatan yang dilakukan dalam analisis data adalah dengan cara data yang diperoleh di analisis secara deskriptif kualitatif.

\section{PEMBAHASAN}

\section{Pelepasan Hak atas Tanah Dati}

Pasal 1 butir 6 Perpres No 65 Tahun 2006 tentang Pengadaan Tanah Bagi Pelaksanaan Pembangunan Untuk Kepentingan Umum menyatakan bahwa Pelepasan atau penyerahan hak atas tanah adalah kegiatan melepaskan hubungan hukum antara pemegang hak atas tanah dengan tanah yang dikuasainya dengan memberikan ganti rugi atas dasar musyawarah. Tanah-tanah yang dibebaskan dengan mendapat ganti kerugian berupa :

a) Uang;

${ }^{8}$ Harsono, Boedi. (2007). Hukum Agraria Indonesia, Sejarah Pembentukan Undang-Undang Pokok Agraria, Isi Dan Pelaksanaannya, Jakarta: Djambatan, h..334.

${ }^{9}$ Effendi, Ziwar. Loc. Cit. h. 92 
b) Tanah Pengganti;

c) Pemukiman Kembali;

Pelepasan hak atas tanah dapat diserahkan secara sukarela atau ada ganti rugi kepada pemilik tanah. Penyerahan secara sukarela atau dengan ganti rugi inilah yang disebut melepaskan hak, dalam prakteknya istilah sukarela itu tidak murni lagi, sebab ada unsur ganti rugi. Dalam bahasa sehari-hari penyerahan sukarela seperti itu adalah akibat tindakan penggusuran oleh suatu pihak yang menang dalam sengketa tanah di pengadilan.

Sejak zaman dahulu, masyarakat adat di kota Ambon sudah mengenal pelepasan atau penyerahan hak atas tanah adat atau tanah dati dengan cara melalui adat sebelum berlakunya Undang-Undang No. 5 Tahun 1960 tentang Undang-Undang Pokok Agraria (UUPA) hal ini juga masih berlaku di masyarakat adat di kota Ambon yang belum memiliki sertifikat tanah baik tanah pekarangan, maupun tanah pertanian.

Masyarakat Adat kota Ambon melakukan pelepasan atau penyerahan hak atas tanah dengan cara sebagai berikut:

1) Warisan

Pemembagian warisan menurut masyarakat adat kota Ambon dilakukan sebelum pewaris meninggal dunia. Masyarakat Ambon menghitung hubungan keturunan berdasarkan garis ayah atau laki-laki (patrilineal), karena keturunan dari Ayah adalah sebagai pemangku yang artinya tanggung jawab meneruskan generasi Ayah atau keturunan laki-laki. Dan yang berhak mewarisi warisan dari pewaris adalah keturunan anak laki-laki.

2) Hibah

Menurut Pasal 1666 Kitab Undang-Undang Hukum Perdata (BW), Hibah yaitu suatu persetujuan dengan mana seorang penghiba menyerahkan suatu barang secara Cuma-Cuma, tanpa dapat menariknya kembali, untuk kepentingan seseorang yang menerima penyerahan barang itu.

Masyarakat adat kota Ambon mengenal suatu bentuk pemberian yang tidak berbeda dengan Hukum Nasional yaitu Hibah. Bentuk pemberian seperti ini diberikan kepada seseorang yang diluar dari ahli warisnya secara cuma-cuma karena penerima hibah tersebut mempunyai sifat dan sikap kesehariannnya dari sisi masyarakat adat kota dianggap baik terutama pemberi hibah dan diberikan semasa pemberi hibah masih hidup.

3) Wasiat

Masyarakat adat kota Ambon juga mengenal Wasiat dengan kata lain perjanjian sepihak. Pemberi wasiat memberikan sesuatu benda kepada penerima wasiat selagi pemberi wasiat masih hidup dan penerima wasiat menerima setelah pemberi wasiat meninggal dunia. Wasiat yang dikenal oleh masyarakat adat kota Ambon tidak jauh berbeda dengan Wasiat yang dikenal dalam Hukum Islam dan BW (burgelijk wetboek), baik tentang syarat-syarat benda yang diwasiatkan maupun tata cara pelaksanaan penyerahan dari pemberi wasiat kepada penerima wasiat.

4) Jual Beli

Setiap manusia sudah tentu mengenal apa yang disebut dengan jual beli tentang arti dan tujuan. Jual beli yang dikenal dengan berbagai macam-macam cara yaitu menggunakan alat tukar dan juga sering digunakan pembayaran dengan barang (barter). Masyarakat adat kota Ambon juga mengetahui tentang cara jual beli tersebut termasuk dalam pelepasan hak atas tanah melalui jual beli. 
Pada masyarakat adat kota Ambon Jual beli tanah dilaksanakan dengan cara perjanjian jual beli hanya berlaku secara lisan dengan dua orang saksi atau lebih, dianggap telah sah menurut hukum adat kota Ambon termasuk jual beli tanah adat, tetapi dengan adanya perkembangan zaman maka masyarakat adat kota Ambon telah mengenal perjanjian jual beli dibuat secara tertulis dan ditandatangani oleh kedua belah pihak dihadapan dua orang saksi, dihadapan tokoh adat dan mengetahui kepala desa.

5) Wakaf

Mengingat pentingnya persoalan tentang wakaf ini, maka Undang-Undang Pokok Agraria (UUPA) Nomor 5 Tahun 1960 telah mencantumkan adanya suatu ketentuan khusus sebagaimana tersebut dalam Pasal 49 ayat (3) yang menyatakan bahwa perwakafan tanah milik dilindungi dan diatur dengan Peraturan Pemerintah. Pada prinsipnya Pasal 49 ayat (3) tersebut merupakan penjelasan fungsi sosial hak-hak atas tanah yang bersandar pada hukum Islam. Perwakafan tanah milik telah diatur sesuai dengan Undang-Undang Nomor 41 Tahun 2004 tentang Wakaf $J o$ Peraturan Pemerintah No. 42 tahun 2006 tentang Pelaksanaan Undang-Undang Nomor 41 Tahun 2004 Tentang Wakaf. Status hukum bagi tanah wakaf sangat penting artinya antara lain bagi pemanfaatan tanah wakaf sesuai dengan tujuan perwakafan itu sendiri. Sehingga diharapkan berlakunya Undang-undang Nomor 41 tahun 2004 ini dapat memenuhi hakekat dan tujuan perwakafan. ${ }^{10}$

Cara pelepasan atau penyerahan hak atas tanah berdasarkan adat kota Ambon yang penulis uraikan diatas, tidak jauh berbeda dengan Undang-Undang No. 5 Tahun 1960 tentang Peraturan Dasar Pokok-Pokok Agraria. Walaupun sampai pada saat ini sebagian masyarakat kota Ambon melakukan peralihan hak atas tanah masih dengan cara adat tetapi harus disahkan atau didaftarkan sebagaimana yang telah cantumkan pada UUPA dan Peraturan Pemerintah Nomor 24 Tahun 1997 Tentang Peralihan Hak atas Tanah untuk memperoleh hak baru dalam bentuk sertipikat hak milik.

\section{Pelaksanaan Pendaftaran Tanah Berdasarkan Surat Pelepasan Hak}

Tanah-tanah di negeri atau desa kebanyakan sudah dikuasai secara individual oleh marga dan warga masyarakat. Tetapi ada semacam pandangan pada masyarakat bahwa meskipun tanah itu sudah bersifat individual ketika beralih kepada warga non asli, akan berubah menjadi tanah Negara. Konsekuensinya, ketika tanah adat individual yang dilepaskan kepada warga yang bukan anak-negeri itu disertipikatkan, maka proses pensertipikatannya ditempuh melalui proses pemberian hak atas tanah. ${ }^{11}$

Proses Pendaftaran Tanah adat di kota Ambon Setelah terbitnya surat pelepasan hak atas tanah adat yang telah disetujui oleh ketua marga, dan pihak kecamatan atau Desa, maka secara sah akan menjadi sebuah bukti tertulis alas bukti hak yang akan digunakan dalam proses pendaftaran hak.

Secara umum penguasaan atau pemilikan hak atas tanah dapat dibuktikan dengan:

1) bukti-bukti tertulis;

2) keterangan saksi dan/ atas pernyataan yang bersangkutan yang kadar kebenarannya oleh Panitia Ajudikasi, dalam pendaftaran tanah secara sistematik

10 Haar, Ter. (1983). Asas-Asas Dan Susunan Hukum Adat, , Jakarta: Pradnya Paramita, h. 161.

11 Sitorus, Oloan. (2019), Kondisi Aktual Penguasaan Tanah Ulayat Di Maluku: Telaah Terhadap Gagasan Pendaftaran Tanahnya, BHUMI: Jurnal Agraria dan Pertanahan, Vol. 5 No. 2 November, h. 227.

115 |SASI Vo1. 26 No.1, Januari - Maret 2020 
atau oleh Kantor Pertanahan dalam pendaftaran tanah secara sporadik dianggap cukup untuk mendaftarkan hak, pemegang hak, dan hak-hak lain yang membebaninya.

Adanya surat pelepasan hak atas tanah yang dikeluarkan oleh ketua marga atau kepala dati berdasarkan ketentuan tersebut akan digolongkan sebagai bentuk bukti tertulis terhadap penguasaan atas tanah. Akan tetapi hingga saat ini keabsahan surat pelepasan hak atas tanah yang dikeluarkan oleh ketua marga atau kepala dati tersebut terkadang menemui kendala. Berdasarkan kenyataan yang terjadi di lapangan masih banyak ditemukan surat pelepasan hak atas tanah ganda untuk satu bidang tanah atau tumpang tindih atas kepemilikan hak. Hal ini terjadi karena bentuk pengakuan terhadap kepemilikan atas tanah adat di kota Ambon dapat dilakukan berdasarkan keterangan lisan semata.

Selain itu lembaga adat atau badan pemerintahan Negeri adat juga belum memiliki sarana pemetaan yang memadai untuk menginventarisasi tanah-tanah milik adat yang masih ada dan tanah adat yang telah dialihkan hak kepemilikannya. Setelah seseorang memiliki surat pelepasan hak atas tanah adat sebagai bukti kepemilikan atas tanah, selanjutnya akan dilakukan proses pendaftaran tanah pada kantor pertanahan. Kantor Pertanahan kota Ambon merupakan instansi yang berwenang untuk melakukan pendaftaran tanah di wilayah Kota Ambon. Pelaksanaan proses pendaftaran tanah yang dilakukan oleh kantor pertanahan Kota Ambon mengacu pada Peraturan Menteri Agraria Dan Tata Ruang/ Badan pertanahan Nasional Nomor 3 Tahun 1997 tentang Pelaksanaan Peraturan Pemerintah Nomor 24 Tahun 1997 tentang Pendaftaran Tanah.

\section{Kekuatan Mengikat Surat Pelepasan Hak Atas Tanah Adat (Dati)}

Dasar hukum pelepasan hak atas tanah diatur dalam pasal 27 Undang-undang Pokok Agraria Nomor 5 Tahun 1960, yaitu hak milik hapus bila:

a) Tanahnya jatuh kepada Negara;

b) Karena pencabutan hak berdasarkan pasal 18;

c) Karena penyerahan dengan sukarela oleh pemiliknya;

d) Karena ditelantarkan;

e) Karena ketentuan pasal 21 ayat 3 dan 26 ayat 2;

f) Tanahnya musnah.

Jika dicermati ketentuan Pasal 27 huruf c, maka dapat dipahami bahwa pelepasan hak atas tanah adat (dati) di Kota Ambon lebih dikenal dalam bentuk surat pelepasan hak atas tanah sehingga dalam konteks kepemilikan hak atas tanah adat (dati) harus dapat memahami Konsep Hak Milik yang dapat dilihat dalam Pasal 570 KUHPerdata yang menyatakan Hak Milik adalah:

" Hak untuk menikmati suatu barang lebih leluasa dan untuk berbuat terhadap barang itu secara bebas sepenuhnya, asalkan tidak bertentangan dengan undangundang atau peraturan umum yang ditetapkan oleh kuasa yang berwenang dan asal tidak menggangu hak-hak orang lain; kesemuanya itu tidak mengurangi kemungkinan pencabutan hak demi kepentingan umum dan penggantian kerugian yang pantas, berdasarkan ketentuan-ketentuan perundangan-undangan".

Dengan demikian surat pelepasan yang dikeluarkan oleh kepala dati sebagai pemilik tanah adat (dati) mempunyai kekuatan mengikat sepanjang dilekati Hak Milik dari pemilik tanah adat (dati) tersebut sebagaimana yang diatur dalam Pasal 584 KUHPerdata, 
yaitu hak milik dapat diperoleh dengan cara:

a) Pemilikan;

b) Pelekatan;

c) Daluwarsa;

d) Pewarisan menurut undang-undang maupun menurut surat wasiat;

e) dan karena penunjukan atau penyerahan.

Sehingga perbuatan hukum yang dilakukan dalam bentuk pelepasan hak atas tanah adat dapat bersifat mengikat, dalam Pasal 20 UUPA telah mengatur secara jelas tentang Hak Milik, yaitu hak turun temurun, terkuat, terpenuh yang dapat dimiliki oleh seseorang atas tanah dimana hak milik atas tanah dapat dialihkan dan beralih kepada orang lain dengan memperhatikan bahwa tanah mempunyai fungsi social, dengan demikian selama dapat dibuktikan kepemilikannya dan tidak dapat dibuktikan sebaliknya maka Surat pelepasan Hak atas Tanah yang dikeluarkan mempunyai kekuatan mengikat sehingga menjadi dasar untuk diterbitkan sertipikat hak milik yang baru.

\section{P E N U T U P}

Pelaksanaan pendaftaran tanah untuk memperoleh hak baru berdasarkan surat pelepasan hak atas tanah adat (dati) di Kota Ambon diberlakukan sama dengan pendaftaran tanah menggunakan pelepasan hak atas tanah pada umunya, hal ini diberlakukan sesuai dengan Peraturan Pemerintah No. 24 Tahun 1997 tentang Pendaftaran Tanah. Proses pendaftaran tanah hak adat (dati) didasarkan pada pelepasan hak adat (dati) yang dikeluarkan oleh pemilik tanah adat (dati) sebagai alas hak untuk memperoleh bukti kepemilikian tanah atau sertipikat.

Surat pelepasan hak atas tanah adat (dati) di kota Ambon yang diterbitkan oleh pemerintah negeri adat atau kepala dati di Kota Ambon bersifat mengikat sepanjang dilakukan berdasarkan hukum adat yang berlaku dan dapat dibuktikan dasar hak kepemilikan atas tanah adat (dati) dari pemilik tanah adat (dati) yang mengeluarkan surat pelepasan hak atas tanah tersebut.

\section{DAFTAR PUSTAKA}

\section{Buku}

[1] Effendi, Ziwar. (1987). Hukum Adat Ambon-Lease. Jakarta: Pradnya Paramita.

[2] Haar, Ter. (1983). Asas-Asas Dan Susunan Hukum Adat, , Jakarta: Pradnya Paramita

[3] Hutagalung, Arie S. (2005). Tebaran Pemikiran Seputar Masalah Hukum Tanah, Jakarta: Lembaga Pemberdayaan Hukum Indonesia.

[4] Harsono, Boedi. (2007). Hukum Agraria Indonesia, Sejarah Pembentukan UndangUndang Pokok Agraria, Isi Dan Pelaksanaannya, Jakarta: Djambatan.

[5] Salindeho, John. (1987). Masalah Tanah Dalam Pembangunan, Jakarta: Sinar Grafika.

[6] Suseno, Franz Magnis. (2001). Etika Politik dan Prinsip-prinsip Moral Dasar Negara Modern, Jakarta: Gramedia.

\section{Jurnal dan Lain-Lain}

[7] Shidarta, (2010), "Peragaan Pola Penalaran Hukum dalam Kajian Putusan Kasus Tanah Adat”. Jurnal Yudisial, Vol-III/No-03/Desember/2010. 
[8] Sitorus, Oloan. (2019), Kondisi Aktual Penguasaan Tanah Ulayat Di Maluku: Telaah Terhadap Gagasan Pendaftaran Tanahnya, BHUMI: Jurnal Agraria dan Pertanahan, Vol. 5 No. 2 November.

[9] Uktolseja, Novyta, (2015). Perkembangan Sistim Pewarisan Tanah Dati di Kota Ambon. Disertasi, Universitas Airlangga. 